\title{
Histology of Luminal Breast Cancer
}

\author{
Ramona Erber Arndt Hartmann \\ Institute of Pathology, University Hospital Erlangen, Friedrich Alexander University Erlangen-Nürnberg (FAU), \\ Comprehensive Cancer Center Erlangen-EMN, Erlangen, Germany
}

\section{Keywords}

Luminal A · Luminal B · Breast cancer - Estrogen receptor . Histological subtypes

\begin{abstract}
Background: Invasive breast cancer (IBC) can be categorized into prognostic and predictive molecular subtypes (including luminal breast cancer) using gene expression profiling. Luminal IBC comprises a variety of histological subtypes with varying clinical and pathological features. Summary: IBC of no special subtype is the most common histological subtype in general and likewise within luminal IBC. Classical invasive lobular breast cancer, typically clustering into luminal subgroup, is characterized by discohesive growth and loss of E-cadherin expression. Infrequent, morphologically distinct luminal IBC subtypes are tubular, invasive cribriform, mucinous, and invasive micropapillary carcinomas. Breast carcinoma with apocrine differentiation, with characteristic expression of androgen receptor (AR), often clusters into the luminal AR category. Rarely, neuroendocrine neoplasms of the breast can be seen. IBC of the male breast usually matches with the luminal subtype. Key Messages: Independently from histological subtypes, invasive breast cancer (IBC) can be divided into molecular subtypes based on mRNA gene expression levels. Using this molecular subtyping, risk scores based on gene expression profiling (established for hormone receptor-positive, HER2-negative IBC), grading, and $\mathrm{Ki}-67$ index, prognosis of patients with luminal breast cancer and response to chemotherapy can be predicted. In routine diagnostics, the expression of estrogen receptor (ER) and progesterone receptor (PR), HER2 status, and the proliferation rate (Ki-67) are used to determine a surrogate (molecular-like) subtype. Within luminal(-like) IBC, no special sub-
\end{abstract}

type and invasive lobular breast carcinoma are the most common histological subtypes. Other rare histological subtypes (e.g., tubular carcinoma) should be recognized due to their distinct clinical and pathological features.

๑) 2020 S. Karger AG, Basel

\section{Introduction}

Invasive breast cancer (IBC) comprises a wide spectrum of histological subtypes [1]. The most frequent subgroup $(40-80 \%)$ is named IBC of no special subtype (NST), formerly known as invasive ductal carcinoma [25]. The second most common histological subtype is invasive lobular breast carcinoma (ILBC). Besides these 2 subtypes, several subtypes with specific histological features exist, for example, mucinous adenocarcinoma and invasive micropapillary carcinoma of the breast [4].

Due to their prognostic and predictive relevance, the expression of biomarkers such as estrogen receptor (ER), progesterone receptor (PR), HER2 status, and the determination of the proliferation rate (Ki-67) are recommended to be assessed in international and national guidelines [6-10]. In routine diagnostics, these 4 markers are evaluated using immunohistochemistry (IHC; ER, $\mathrm{PR}, \mathrm{Ki}-67$ ) and IHC and/or in situ hybridization (ISH; HER2 status), according to international and national guidelines. In order to ensure adequate marker assessment, participation in internal and external quality assurances is required $[7,8,11]$.

Besides the morphological distinction into different histological subtypes, which are associated with prognosis, recurrence pattern, and therapy response but cannot sufficiently predict the underlying tumor biology, IBC 
Table 1. Definition of surrogate subtypes of luminal IBC according to 13th St. Gallen International Breast Cancer Conference (2013) Expert Panel and 5th edition of the WHO Classification of Tumors (2019) [16, 17]

\begin{tabular}{cllll}
\hline & ER & PR & HER2 & Ki-67 \\
\hline $\begin{array}{l}\text { Luminal A like } \\
\text { Luminal B like } \\
\text { HER2 negative }\end{array}$ & Positive & Positive & Negative & Low \\
PER2 positive & Positive & $\begin{array}{l}\text { Negative or low } \\
\text { and/or high Ki-67 } \\
\text { Any }\end{array}$ & Negative & $\begin{array}{l}\text { High and/or } \\
\text { PR negative or low } \\
\text { amplification }\end{array}$ \\
\hline
\end{tabular}

can be subdivided into intrinsic (molecular) subtypes based on mRNA gene expression levels. These molecular subgroups, including luminal A (40-60\%) and luminal B IBC (20-30\%) [12], were shown to have both prognostic (outcome without any therapy) and predictive relevance (e.g., response to endocrine therapy, anti-HER2 therapy, or chemotherapy) [13-15]. Currently, ER, PR, HER2, and $\mathrm{Ki}-67$ status, as described above, are used to determine these subtypes in daily routine [16].

In this review, we will recapitulate the definition of luminal IBC and summarize the histological subtypes of luminal IBC.

\section{Histology of Luminal Breast Cancer}

\section{Clinicopathological Definition of Luminal IBC}

Using IHC

According to the 13th St. Gallen International Breast Cancer Conference (2013) Expert Panel and the 5th edition of the WHO Classification of Tumours, Breast Tumours (2019), luminal tumors are classified using an IHC/ISH panel including the 2 hormone receptors (HR) ER and PR, HER2, and Ki-67 (Table 1). All 3 luminal types (luminal A like; luminal B like, HER2 negative; luminal B like, and HER2 positive) share a positive ER IHC. In contrast, PR, HER2, and Ki-67 are helpful to distinguish these subtypes $[16,17]$.

\section{Histology and Grading of HR-Positive (Luminal-Like) \\ Breast Cancer}

A variety of histomorphological subtypes and grades can be seen in luminal(-like) breast cancer. Some display tubular structures with low nuclear pleomorphism, some grow in a solid pattern, and some exhibit high-grade nuclei. If breast carcinomas display a combination of strong ER IHC and HER2 negativity, the tumors are often of grade G1 or G2 but can also display G3 differentiation. Especially low ER-positive breast cancer are often highgrade (G3) tumors and match with nonluminal molecular subtypes $[18,19]$.

\section{IBC of No Special Type}

IBC of no special type (NST) was formerly named invasive ductal carcinoma due to its resemblance to breast ductules in varying forms and is still recommended to be termed invasive ductal carcinoma not otherwise specified by some authors. It comprises a wide spectrum of morphologies that do not display features of any special morphological breast cancer type. They can grow in tubules with distinct lumina (ductal differentiation), trabecularly, or solidly with nests or cords (Fig. 1A, B). Desmoplastic stroma can be seen to a varying extent. Tumor nuclei may be pleomorphic with easily recognizable nucleoli. Necrotic areas, apoptosis, and frequent mitoses can be absent or marked, and even metaplasia occurs in some cases $[2,20]$. For therapy stratification, this subtype is divided into the molecular-like subtypes using ER, PR, HER2, Ki-67, and grading [17, 21-23]. ER positivity is found in $61-80 \%$ of IBC (Fig. 1C), and HER2 positivity in 15\% [24, 25]. In HRpositive breast cancer, up to $96 \%$ display the histological features of IBC NST [26]. Within the HR-positive, HER2negative IBC, the luminal A molecular subtype often comprises IBC NST G1, but it may also be of higher grade. IBC NST G2 tumors might match with the luminal B category in some cases [1]. However, grade and molecular subtype do not imply each other. Hence, further stratification of some G2 but also some G1 and G3 HR-positive, HER2negative tumors using Ki-67 and/or multigene expression analysis may be useful to uncover the biological behavior of the tumor, especially if further clinical or pathological high-risk characteristics are lacking.

\section{Mixed IBC NST}

Mixed IBC NST is composed of an IBC NST component and a special histological subtype in 10-90\% [27]. Hence, molecular(-like) subtyping depends on the tumor cell populations involved.

\section{Invasive Carcinoma with Neuroendocrine Differentiation}

This subtype of IBC is described later in the chapter Neuroendocrine Neoplasms of the Breast. 


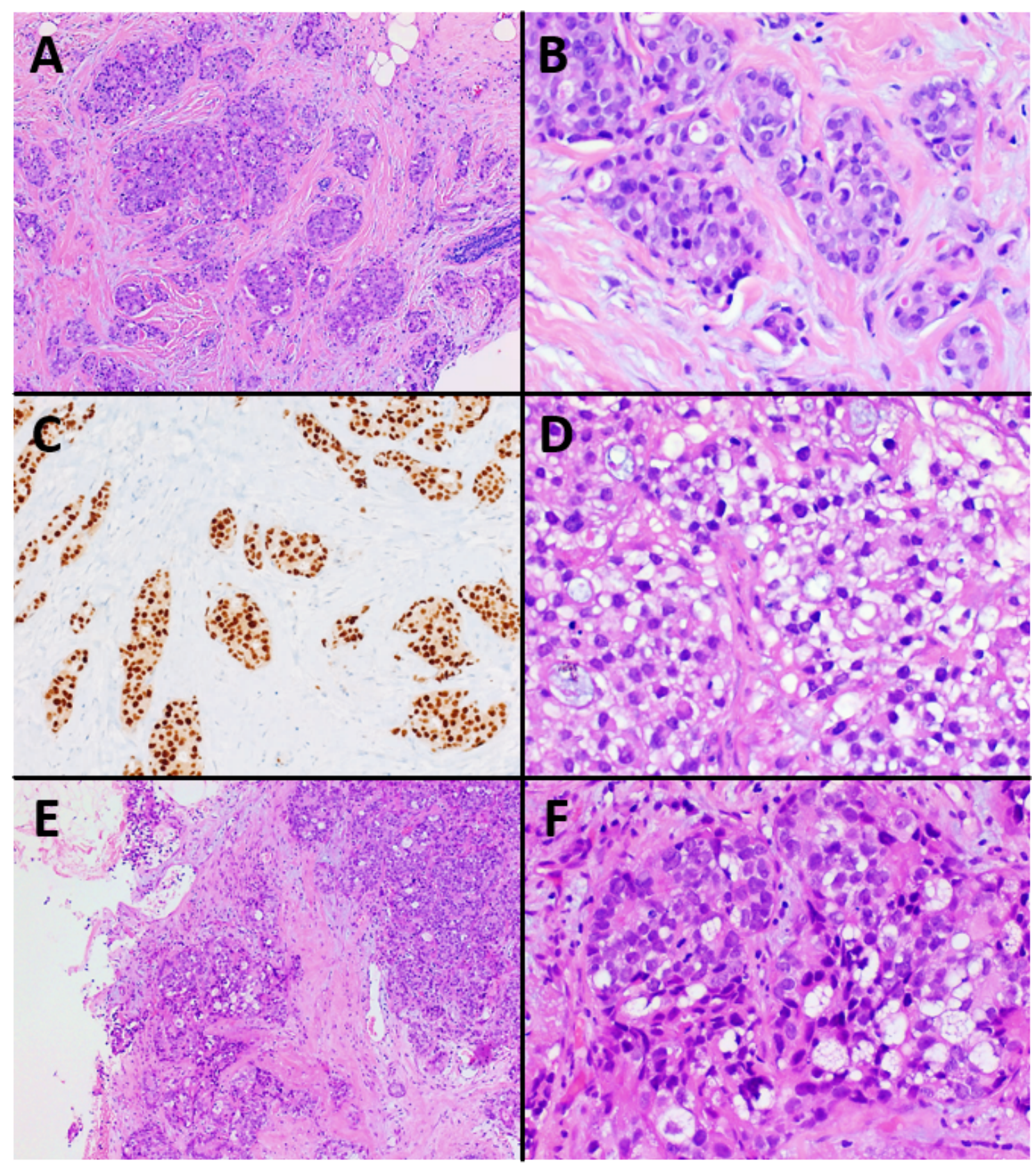

Fig. 1. Luminal-like invasive breast cancer of no special subtype (IBC NST) and rare patterns of IBC NST. A-C Histology of IBC NST, intermediate grade (G2): solid and tubular growth of carcinoma cells surrounded by stromal desmoplasia. Estrogen receptor (ER) expression is strong and homogeneous. A H\&E. $\times 100$. B H\&E. $\times 400$. C ER immunohistochemistry. $\times 200$. D Glycogen-rich clear-cell pattern of IBC NST with predominantly clear cytoplasm due to accumulation of glycogen. D H\&E. $\times 400$. E, F Sebaceous pattern of IBC NST with typical characteristics of sebaceous cells with abundant and vacuolated cytoplasm. E H\&E. $\times 100$. F H\&E. $\times 400$.

\section{Oncocytic Pattern of IBC NST}

Some IBC (up to $19.7 \%$ ) show oncocytic features, that is, they have a granular and eosinophilic cytoplasm due to an increased number of mitochondria. Usually, they display a solid growth pattern and belong predominantly to the luminal subtype with ER positivity in up to $78 \%$ and PR positivity in $62.5 \%$. Twenty-five percent of these tumors present with a positive HER2 status. Regarding clin- ical features and prognosis, they do not differ from conventional IBC NST [28-30].

\section{Glycogen-Rich Clear Cell Pattern}

This rare histological subgroup is characterized by a clear or finely granular cytoplasm rich in glycogen (Fig. 1D). The architecture, including nests and cords, is mostly comparable to IBC NST. However, a lobular or 


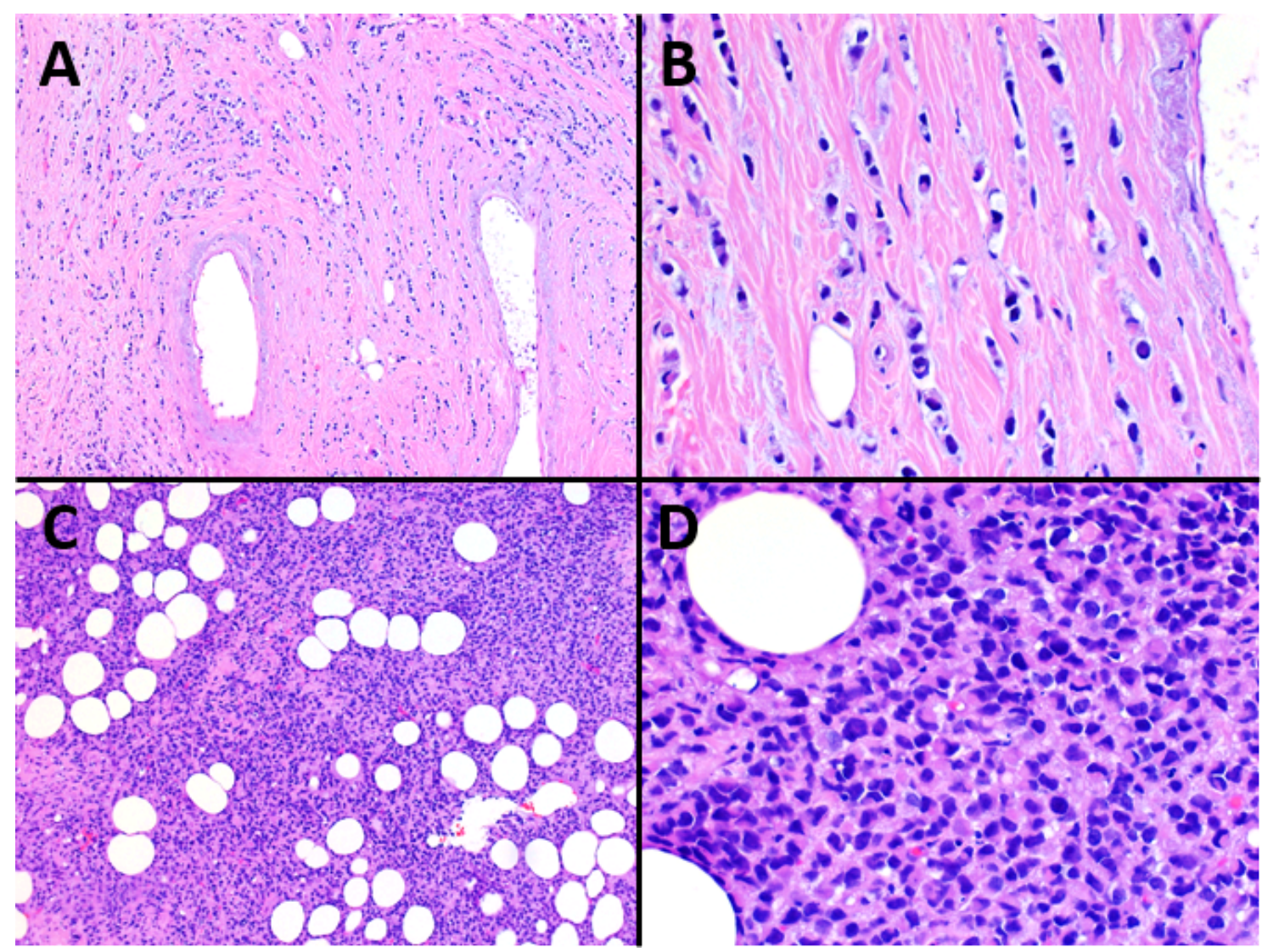

Fig. 2. Patterns of invasive lobular breast carcinoma. A, B Histology of classical invasive lobular breast carcinoma (ILBC), intermediate grade (G2). Discohesive tumor cells are diffusely dispersed as single cells or grow loosely in a linear single-file pattern. A H\&E. $\times 100$. B H\&E. $\times 400$. C, D Pleomorphic ILBC, high grade (G3) with pleomorphic and hyperchromatic nuclei and increased mitotic activity. C H\&E. $\times 100$. D H\&E. $\times 400$.

tubular growth pattern can be detected in some cases. Cell borders are sharply demarcated, and the tumor cells are often polygonal with hyperchromatic nuclei and a typically high mitotic rate. Some of these tumors fulfill the criteria of luminal IBC with ER being positive in $35-62 \%$. However, PR is mostly negative [31-34].

\section{Sebaceous Pattern of IBC NST}

The sebaceous pattern is a very rare differentiation in IBC. The characteristic tumor cells, which originate from breast parenchyma, display abundant vacuolated cytoplasm typical for sebaceous cells (Fig. 1E, F). A cutaneous adnexal tumor arising from sebaceous glands has to be excluded. Immunohistochemically, these tumors express adipophilin. Some IBC NST with a sebaceous pattern show a luminal-like subtype with ER/PR often being positive and HER 2 mostly being negative [35-39].

\section{Invasive Lobular Breast Carcinoma}

In $5-15 \%$ of IBC, a peculiar lobular growth pattern, which led to the term "lobular carcinoma" back in 1941, can be found $[5,40]$. The classical invasive lobular breast carcinoma shows discohesive, singly dispersed - or in a socalled single-file linear and targetoid pattern arranged small- or medium-sized, mostly uniform tumor cells with round nuclei, inconspicuous nucleoli, and typical central mucoid globules and is of intermediate grade (Fig. 2A, B). Besides ILBC variants with solid, trabecular, alveolar, signet-ring cell, histiocytoid, or apocrine differentiation, pleomorphic ILBC exists. These tumors display ample, eosinophilic cytoplasm, large, hyperchromatic high-grade nuclei, and an increased mitotic activity (Fig. 2C, D). A characteristic feature of ILBC is the IHC loss of E-cadherin, a cell-cell adhesion molecule, resulting in the peculiar discohesive growth pattern. Typically, up to $100 \%$ of classic ILBC and its variants express ER, and $60-70 \%$ are PR positive. In general, HER2 positivity is rare in ILBC. Using gene expression analysis, most of ILBC cluster into the luminal A molecular subgroup, less frequently into luminal $\mathrm{B}$, and rarely into nonluminal subtypes. In pleomorphic and apocrine ILBC, however, ER expression levels are decreased, and positive HER2 status may be seen. Furthermore, the histiocytoid variant of ILBC often harbors positive androgen receptor (AR) expression, whereas the tu- 


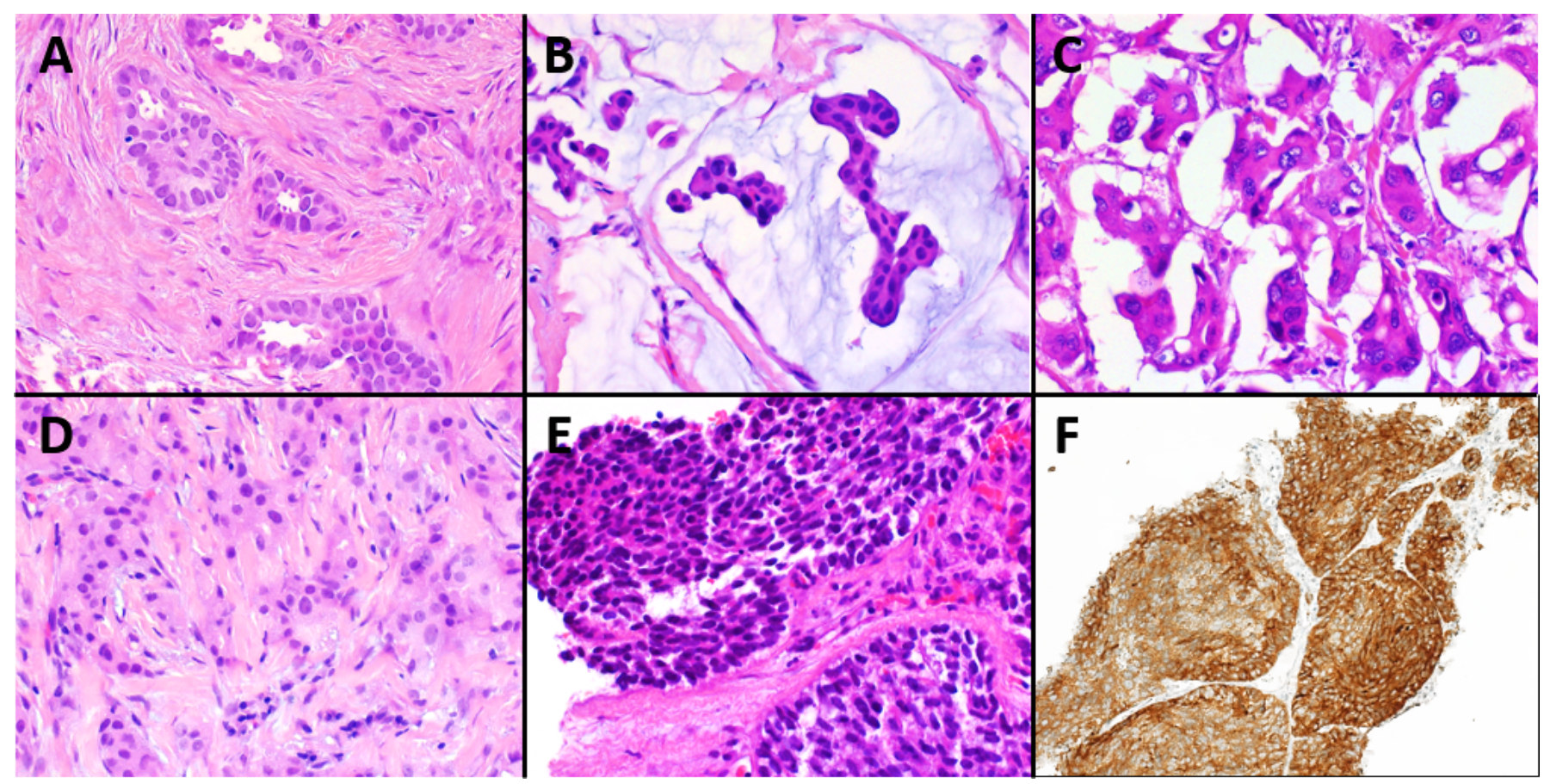

Fig. 3. Rare histological subtypes of luminal breast cancer. A Histology of tubular carcinoma of the breast, low grade (G1). Tubular growth in $>90 \%$ of the tumor, no marked pleomorphism of the nuclei and no increased mitotic activity. H\&E. $\times 400$. B Mucinous carcinoma with tumor cells floating in mucin. H\&E. $\times 400$. C Invasive micropapillary breast carcinoma with morula-like tumor cell clusters surrounded by small sinus-like spaces. H\&E. $\times 400$. D Breast carcinoma with apocrine differentiation with granular eosinophilic cytoplasm. H\&E. $\times 400$. E Invasive breast cancer with neuroendocrine features including positivity for synaptophysin. H\&E. $\times 400$. F Synaptophysin immunohistochemistry. $\times 200$. mor cells are negative for ER and PR. The "Rosen triad" (lobular neoplasia, columnar cell change, and tubular carcinoma) as well as tubulolobular carcinoma, which is regarded as a variant of ILBC by some authors, but as a subgroup of tubular carcinoma by other authors, are discussed below $[5,41-51]$.

\section{Other Less-Frequent Histological Subtypes with Luminal Features}

\section{Tubular Carcinoma}

The rarely (2.2\%) [52] occurring tubular carcinoma of the breast is defined by its unique appearance showing well-defined glands and irregularly shaped and angular tubules with wide lumina in $>90 \%$ of the tumor, hence, mimicking nonneoplastic mammary ductules. However, there is only a single-cell layer of cuboidal or columnar neoplastic cells without evidence of basal myoepithelial cells. The basal nuclei typically display an oval or round shape and low-grade atypia. There is no marked pleomorphism of nuclei or necrosis; nuclei are inconspicuous. Only few mitoses should be counted (Fig. 3A). In most cases (up to 98\%), tumors are well differentiated (G1); very rarely, they are of intermediate grade (G2). The tu- mor stroma is ample and often shows elastosis. The outcome of affected patients is very favorable [4, 53-57]. Interestingly, tubular carcinoma may be associated with coexisting lobular neoplasia and columnar cell lesions ("Rosen triad") [58]. Hence, the pathologist should search for small foci of lobular neoplasia or ILBC in case of tubular carcinoma. Typically, there is homogeneous and strong ER staining [59] in tubular carcinoma with positivity of PR in 69-75\%. Immunohistochemically, further luminal markers are positive in $86-100 \%$ (CK7/8, CK18, and CK19), whereas basal markers like CK5/6 and CK14 are predominantly negative. Furthermore, HER2 is usually negative $[55,60]$. Ki-67 IHC usually displays a proliferation rate $<10 \%$ [61]. By IHC, hence, tubular carcinoma shows typically a luminal A- or luminal B-like protein expression [62]. Using gene expression analysis, tubular carcinoma clusters into the luminal breast cancer subtype [4].

Tubulolobular IBC, which contains growth patterns of both ILBC and tubular carcinoma and is typically ER/PR positive and HER2 negative [63], is rather a variant of tubular/ductal carcinoma than of ILBC. Although mimicking the ILBC growth pattern, tubulolobular IBC displays retained membranous staining of E-cadherin, which is lost in classical ILBC $[64,65]$. However, it has to be noted 
that the corresponding references are not mentioned in the 4 th and 5 th edition of the WHO Classification of Tumours of the Breast, in which tubulolobular carcinoma has been grouped as a variant of ILBC. Regardless of this controversy, gene expression analysis has proven transcriptomic similarities between tubular carcinoma and ILBC which might explain some particular overlap between ILBC, tubulolobular carcinoma, and tubular carcinoma [4].

\section{Invasive Cribriform Carcinoma}

Another very rare (0.2-3.5\%) morphological subgroup is invasive cribriform carcinoma (ICC) of the breast $[5,52,66]$. If the typical pattern constitutes $>90 \%$ (pure ICC), the prognosis is excellent, whereas mixed ICC approaches survival rates similarly to IBC NST [67]. Surrounded by stromal desmoplasia, multiple nests of neoplastic epithelium with round, sharp, "Swiss cheese"like cutouts (so-called cribriform, fenestrated, or sievelike pattern) can be seen. In contrast to cribriform ductal carcinoma in situ, ICC is truly invasive, lacking the myoepithelial basal layer. Tumor cells are typically well differentiated and uniform; there should be no marked pleomorphism or high mitotic activity (mostly G1 tumors). Within the lumina, mucin-positive secretion and also microcalcifications may be detectable. Rarely, ICC may contain areas with tubular architecture (up to 50\%) [68-70]. Furthermore, ICC is often accompanied (80\%) by typically cribriform or micropapillary ductal carcinoma in situ of low or intermediate grade. 96\% of ICC are ER positive, and most (89\%) are PR positive as well, but 90-98\% are HER2 negative. Moreover, Ki-67 expression is low [5, 70-72].

\section{Mucinous Adenocarcinoma of the Breast}

Mucinous carcinoma (MC) (2.2-3.6\% of breast carcinomas) is characterized by islands of neoplastic epithelial cells floating in extracellular mucin (Fig. 3B) [52, 73, 74]. Besides pure MC containing a mucinous component of $>90 \%$, mixed MC also (mucinous component in 10-90\%) exists $[75,76]$. However, some authors recommend to term tumors with a mucinous component $<50 \%$ IBC with focal mucinous differentiation. Neoplastic epithelial cells grow in an alveolar or cribriform pattern, ribbons, and strands or papillary aggregates. Depending on the distribution of mucin and epithelial components, growth pattern, and cytology of tumor cells, MC can be divided into type A, type B, or type AB [77]. Nuclei in MC are mostly of low or intermediate grade [76], and tumors are often of good or moderate differentiation. However, prior studies and our own experience have shown that G3 MC exists in up to $9 \%$ [78]. In some cases, pure MC harbors areas with micropapillary features of the epithelial component. Within extracellular mucin, there are small clusters or ring-like structures of cohesive tumor cells with everted polarity, which can be demonstrated using epithelial membrane antigen IHC $[79,80]$. Prognosis of pure MC is superior compared with IBC NST, whereas MC with a micropapillary component shows poorer outcome than conventional pure MC $[79,81]$. Using IHC, ER and PR are typically expressed positively $[79,81]$. Infrequently, HER2 positivity can be found $[4,82]$. However, MC with a micropapillary pattern may be HER2 positive [79]. Mean percentage of $\mathrm{Ki}-67$ expression was reported to be $17 \%$ [62]. In general, MC matches with the luminal molecular-like subgroup (98\%, assessed using IHC) [62] and the luminal molecular subgroup (microarray expression profiling) [4].

\section{Invasive Micropapillary Breast Carcinoma}

Micropapillary growth is defined by morula-like neoplastic epithelial clusters without any fibrovascular core (compared to papillary growth). These aggregates are surrounded by small sinus-like empty spaces followed by a delicate stromal network ("exfoliative appearance"; Fig. 3C). The epithelial nests are characterized by a reversed polarity, that is, the luminal part appears on the outside of the cell aggregates ("inside out"), and, mostly, the carcinoma is of intermediate or high grade (G2/G3). Pure invasive micropapillary carcinoma contains $>90 \%$ of this peculiar growth pattern and is found in up to $2 \%$. However, up to $7.4 \%$ of IBC are reported to show some minor micropapillary areas. Usually, invasive micropapillary carcinomas show an ER- and PR-positive phenotype. HER2 positivity is variable. By gene expression analysis, invasive micropapillary carcinoma often matches with the luminal subtype. Outcome data are controversial. However, increased lymphovascular invasion is seen in this special subtype compared to IBC NST $[4,5$, 83-90].

\section{Breast Carcinoma with Apocrine Differentiation}

In $<4 \%$ of IBC $[5,91]$, tumor cells display a specific apocrine differentiation with abundant granular eosinophilic (type A cells), partly vacuolated cytoplasm (type B cells), intermediate-to-high-grade differentiation with large nuclei with prominent atypia including hyperchromatic and irregular nuclear membranes and marked nucleoli in combination with positivity for the hormone receptor androgen receptor (AR) (Fig. 3D). Tumor cells mostly grow cohesively in small- to medium-sized nested formations with additional stromal desmoplasia and accompanying lymphocytic inflammatory infiltrates, especially in G3 tumors. However, ER and PR are typically negative; only few cases with ER/PR positivity are reported. Positive HER2 status is found in 30-60\%. Alterations in the PIK3CA/PTEN/AKT pathway are frequent. In the Cowden syndrome (germline mutation of PTEN), breast 
cancer with apocrine differentiation is reported to be a typical finding. Using gene expression analysis, breast carcinoma with apocrine differentiation clusters into several intrinsic subtypes including luminal (ER+), HER2-enriched, and the molecular apocrine (synonym luminal AR) subgroup. The latter does not completely overlap with the histological subtype (breast cancer with apocrine differentiation) [92]. Due to the fact that the histological subtype with apocrine differentiation does not perfectly match with the molecular apocrine group and that other histological subtypes may show apocrine features as well, breast cancer with apocrine differentiation was not recognized as distinct entity by the WHO Classification of Tumours in 2012 (in contrast to the latest WHO Classification of 2019) [93]. Interestingly, the AR-induced transcriptional program overlaps in parts with that induced by ER, which may explain that AR partly substitutes ER to induce a luminal gene expression pattern in the absence of ER/PR [94]. The findings regarding prognosis are reported controversially $[4,5$, 95-100].

\section{Neuroendocrine Neoplasms of the Breast and Breast Cancer with Neuroendocrine Differentiation}

\section{Neuroendocrine Tumors}

Rarely, neuroendocrine tumors (NET) arise in the breast. In contrast to IBC with neuroendocrine differentiation, a NET of the breast shows both distinctive histomorphological and marked immunohistochemical features of neuroendocrine differentiation. Besides invasive solid growth in nests or trabeculae, tumor nuclei display a so-called salt-and-pepper chromatin. NET of the breast is of low or intermediate grade (G1 or G2). If there is high-grade neuroendocrine morphology which is immunohistochemically confirmed, the lesion is termed neuroendocrine carcinoma (NEC) of the breast (see below). Expression of synaptophysin and/or chromogranin A should be strong and extensive in NET of the breast. ER and PR are usually strongly positive, whereas HER2 is negative [101-106].

\section{Neuroendocrine Carcinoma}

NEC of the breast is a rare finding. Similar to NET, typical neuroendocrine features have to be displayed both morphologically and immunohistochemically. In contrast to NET of the breast (low- or intermediategrade morphology), NEC shows exclusively high-grade nuclei and high mitotic activity (G3 per definition). Depending on the size of tumor cells, small-cell and largecell NECs are distinguished. HR positivity is found in $30-100 \%$, and HER 2 is reported to be negative $[103,104$, 107-110].

\section{Invasive Carcinoma with Neuroendocrine}

\section{Differentiation}

Ten to $30 \%$ of IBC NST harbor a partial neuroendocrine differentiation [111]. However, the typical distinct neuroendocrine histology and/or the strong IHC expression of neuroendocrine markers are not seen in complete manifestation but only attenuated and inhomogeneously (Fig. 3E, F). These carcinomas should not be mistaken for NET or NEC of the breast showing already histologically a distinct neuroendocrine differentiation [105] which is confirmed by strong and diffuse neuroendocrine marker expression using IHC. Usually, IBC NST with neuroendocrine differentiation harbors HR positivity, whereas HER2 is negative [104, 112]. Furthermore, it is categorized into the luminal $\mathrm{A}$ and the luminal $\mathrm{B}$ molecular subgroup using gene expression analysis $[104,110,113,114]$. It has to be recognized that some IBC with a partial neuroendocrine differentiation may show a lobular or mucinous histological subtype [104].

\section{IBC of the Male Breast}

Less than $1 \%$ of breast cancers occur in men [115]. The most histological subtype is IBC NST of intermediate grade (G2), but papillary, lobular, or mixed growth patterns as well as (rarely) G1 and G3 tumors can occur [116]. Typically, IBC of the male breast harbors ER and/ or PR positivity and HER2 negativity, and matches with luminal A subtype [117].

\section{Conclusion}

Luminal breast cancer, defined by gene expression profiling, contains a wide spectrum of histological subtypes. Herein, the most common subgroup constitutes IBC NST, followed by ILBC, and its variants. However, a variety of special subtypes including micropapillary carcinoma and MC as well as breast tumors with neuroendocrine differentiation cluster into the luminal molecular subgroup.

In clinical routine, IHC expression of ER, $\mathrm{PR}$, and $\mathrm{Ki}$ 67 as well as HER2 status (IHC and/or ISH) are used to define molecular-like surrogate subtypes. This method can be applied even in the special histological subtypes.

Since some luminal(-like) histological subtypes (e.g., tubular carcinoma) differ from IBC NST regarding clinical and pathological characteristics, oncologists and pathologists should be aware of these special luminal(-like) histological subtypes. 


\section{Acknowledgment}

Many thanks to all patients that had given informed consent to participate in all the breast cancer studies mentioned in this review. Furthermore, we thank Mrs. Rudelt for graphical support.

\section{Disclosure Statement}

R.E. has received honoraria from Roche, Novartis, Pfizer, and Eisai, reimbursement of traveling expenses from BioNTech and research funding from NanoString Technologies, Cepheid, BioNTech, and Zytomed Systems. A.H. has received honoraria from Bristol-Myers Sqibb, MSD, Roche, AstraZeneca, Boehringer Ingelheim, Abbvie, Janssen-Cilag, and Ipsen, and research funding from Cepheid, BioNTech AG, Roche, Janssen-Cilag, NanoString Technologies, and AstraZeneca. Moreover, he has acted as consul- tant/in advisory role for Bristol-Myers Sqibb, MSD, Roche, Cepheid, Qiagen, Janssen-Cilag, AstraZeneca, Ipsen, and NanoString Technologies (also expert testimony), Illumina, 3DHISTECH, and Diaceutics.

\section{Funding Sources}

There was no funding for writing this review.

\section{Author Contributions}

R.E. has written the manuscript including literature research. A.H. has reviewed the manuscript. Figures have been prepared by both.

\section{References}

1 Makki J. Diversity of Breast Carcinoma: Histological Subtypes and Clinical Relevance. Clin Med Insights Pathol. 2015 Dec;8:23-31.

2 WHO Classification of Tumours Editorial Board. Breast tumours. WHO classification of tumours series. 5th ed. Vol. 2. Lyon: International Agency for Research on Cancer; 2019. p. 102-4.

3 Moinfar F. Essentials of diagnostic breast pathology. Practical approach. 1st ed. Berlin: Springer; 2007.

4 Weigelt B, Horlings HM, Kreike B, Hayes MM, Hauptmann M, Wessels LF, et al. Refinement of breast cancer classification by molecular characterization of histological special types. J Pathol. 2008 Oct;216(2):14150.

5 Weigelt B, Geyer FC, Reis-Filho JS. Histological types of breast cancer: how special are they? Mol Oncol. 2010 Jun;4(3):192-208.

6 Interdisziplinäre S3-Leitlinie für die Früherkennung, Diagnostik, Therapie und Nachsorge des Mammakarzinoms. Langversion 4.3 - Februar 2020 AWMF-Registernummer: 032-045OL

7 Allison KH, Hammond MEH, Dowsett M, McKernin SE, Carey LA, Fitzgibbons PL, et al. Estrogen and Progesterone Receptor Testing in Breast Cancer: ASCO/CAP Guideline Update. J Clin Oncol. 2020 Apr;38(12):1346-66.

8 Wolff AC, Hammond MEH, Allison $\mathrm{KH}$, Harvey BE, Mangu PB, Bartlett JMS, et al. Human Epidermal Growth Factor Receptor 2 Testing in Breast Cancer: American Society of Clinical Oncology/College of American $\mathrm{Pa}$ thologists Clinical Practice Guideline Focused Update. J Clin Oncol. 2018 Jul;36(20): 2105-22.

9 Arbeitsgemeinschaft Gynäkologische Onkologie V. Guidelines Breast Version 2020.1. [accessed 2020 Apr 26]. Available from: www. ago-online.de.

10 WHO Classification of Tumours Editorial Board. Breast tumours. WHO classification of tumours series. 5th ed. Vol. 2. Lyon: International Agency for Research on Cancer; 2019. p. 88-97.
11 WHO Classification of Tumours Editorial Board. Breast tumours. WHO classification of tumours series. 5th ed. Vol. 2. Lyon: International Agency for Research on Cancer; 2019. p. 89-91.

12 WHO Classification of Tumours Editorial Board. Breast tumours. WHO classification of tumours series. 5th ed. Vol. 2. Lyon: International Agency for Research on Cancer; 2019. p. 92.

13 Perou CM, Sørlie T, Eisen MB, van de Rijn M, Jeffrey SS, Rees CA, et al. Molecular portraits of human breast tumours. Nature. 2000 Aug; 406(6797):747-52.

14 Sørlie T, Perou CM, Tibshirani R, Aas T, Geisler S, Johnsen H, et al. Gene expression patterns of breast carcinomas distinguish tumor subclasses with clinical implications. Proc Natl Acad Sci USA. 2001 Sep;98(19): 10869-74.

15 Parker JS, Mullins M, Cheang MC, Leung S, Voduc D, Vickery T, et al. Supervised risk predictor of breast cancer based on intrinsic subtypes. J Clin Oncol. 2009 Mar;27(8):1160-7.

16 WHO Classification of Tumours Editorial Board. Breast tumours. WHO classification of tumours series, 5th ed. Lyon: International Agency for Research on Cancer; 2019. Vol. 2. p. 96.

17 Goldhirsch A, Winer EP, Coates AS, Gelber RD, Piccart-Gebhart M, Thürlimann B, et al.; Panel members. Personalizing the treatment of women with early breast cancer: highlights of the St Gallen International Expert Consensus on the Primary Therapy of Early Breast Cancer 2013. Ann Oncol. 2013 Sep;24(9): 2206-23.

18 Sheffield BS, Kos Z, Asleh-Aburaya K, Wang XQ, Leung S, Gao D, et al. Molecular subtype profiling of invasive breast cancers weakly positive for estrogen receptor. Breast Cancer Res Treat. 2016 Feb;155(3):483-90.

19 WHO Classification of Tumours Editorial Board. Breast tumours. WHO classification of tumours series. 5th ed. Vol. 2. Lyon: International Agency for Research on Cancer; 2019. p. $90-1$.
20 Rosai J. Rosai and Ackerman's surgical pathology. 10th ed. Elsevier; 2011. p. 1696-8.

21 von Minckwitz G, Untch M, Blohmer JU, Costa SD, Eidtmann H, Fasching PA, et al. Definition and Impact of Pathologic Complete Response on Prognosis After Neoadjuvant Chemotherapy in Various Intrinsic Breast Cancer Subtypes. J Clin Oncol. 2012 May;30(15):1796-804.

22 Gnant M, Harbeck N, Thomssen C. St. Gallen/ Vienna 2017: A Brief Summary of the Consensus Discussion about Escalation and De-Escalation of Primary Breast Cancer Treatment. Breast Care (Basel). 2017 May;12(2):102-7.

23 Untch M, Huober J, Jackisch C, Schneeweiss A, Brucker SY, Dall P, et al. Initial Treatment of Patients with Primary Breast Cancer: Evidence, Controversies, Consensus: Spectrum of Opinion of German Specialists at the 15th International St. Gallen Breast Cancer Conference (Vienna 2017). Geburtshilfe Frauenheilkd. 2017 Jun;77(6):633-44.

24 Sapino A, Kulka J, editors. Breast pathology. Encyclopedia of Pathology. Berlin: Springer; 2020. p. 151.

25 Rosen PP, editor. Rosen's breast pathology. 4th ed. Philadelphia (PA): Lippincott Williams \& Wilkins; 2014. p. 413-52.

26 Pandit P, Patil R, Palwe V, Gandhe S, Patil R, Nagarkar R. Prevalence of Molecular Subtypes of Breast Cancer: A Single Institutional Experience of 2062 Patients. Eur J Breast Health. 2019 Nov;16(1):39-43.

27 WHO Classification of Tumours Editorial Board. Breast tumours. WHO classification of tumours series. 5th ed. Vol. 2. Lyon: International Agency for Research on Cancer; 2019. p. 104.

28 WHO Classification of Tumours Editorial Board. Breast tumours. WHO classification of tumours series. 5th ed. Vol. 2. Lyon: International Agency for Research on Cancer; 2019. p. 107.

29 Ragazzi M, de Biase D, Betts CM, Farnedi A, Ramadan SS, Tallini G, et al. Oncocytic carcinoma of the breast: frequency, morphology and follow-up. Hum Pathol. 2011 Feb;42(2): 166-75. 
30 Geyer FC, de Biase D, Lambros MB, Ragazzi M, Lopez-Garcia MA, Natrajan R, et al. Genomic profiling of mitochondrion-rich breast carcinoma: chromosomal changes may be relevant for mitochondria accumulation and tumour biology. Breast Cancer Res Treat. 2012 Feb;132(1):15-28.

31 Rosen PP. Rosen's breast pathology. 4th ed. Philadelphia (PA): Lippincott Williams \& Wilkins; 2014. p. 757-60

32 WHO Classification of Tumours Editorial Board. Breast tumours. WHO classification of tumours series. 5th ed. Vol. 2. Lyon: International Agency for Research on Cancer; 2019. p. 108.

33 Rosen PP. Rosen's breast pathology. 3rd ed. Philadelphia (PA): Lippincott Williams \& Wilkins; 2008.

34 Tavassoli FA, Eusebi V. Tumors of the mammary gland. AFIP atlas of tumor pathology, series 4; fascicle 10. Washington, DC: America Registry of Pathology; 2009.

35 Varga Z, Kolb SA, Flury R, Burkhard R, Caduff R. Sebaceous carcinoma of the breast. Pathol Int. 2000 Jan;50(1):63-6.

36 Hisaoka M, Takamatsu Y, Hirano Y, Maeda H, Hamada T. Sebaceous carcinoma of the breast: case report and review of the literature. Virchows Archiv. 2006 Oct;449(4):484-88.

37 Murakami A, Kawachi K, Sasaki T, Ishikawa T, Nagashima Y, Nozawa A. Sebaceous carcinoma of the breast. Pathol Int. 2009 Mar; 59(3):188-92.

38 Švajdler M, Baník P, Poliaková K, Straka L, Hríbiková Z, Kinkor Z, et al. Sebaceous carcinoma of the breast: report of four cases and review of the literature. Pol J Pathol. 2015 Jun; 66(2):142-8.

39 WHO Classification of Tumours Editorial Board. Breast tumours. WHO classification of tumours series, 5th ed. Vol. 2. Lyon: International Agency for Research on Cancer; 2019. p. 109.

40 Foote FW, Stewart FW. Lobular carcinoma in situ: A rare form of mammary cancer. Am J Pathol. 1941 Jul;17(4):491-6.3.

41 Porter PL, Garcia R, Moe R, Corwin DJ, Gown AM. C-erbB-2 oncogene protein in in situ and invasive lobular breast neoplasia. Cancer. 1991 Jul;68(2):331-4.

42 Sastre-Garau X, Jouve M, Asselain B, Vincent-Salomon A, Beuzeboc P, Dorval T, et al. Infiltrating lobular carcinoma of the breast. Clinicopathologic analysis of 975 cases with reference to data on conservative therapy and metastatic patterns. Cancer. 1996 Jan;77(1): 113-20.

43 Rakha EA, El-Sayed ME, Powe DG, Green AR, Habashy $\mathrm{H}$, Grainge MJ, et al. Invasive lobular carcinoma of the breast: response to hormonal therapy and outcomes. Eur J Cancer. 2008 Jan;44(1):73-83.

44 Simpson PT, Reis-Filho JS, Lambros MB, Jones C, Steele D, Mackay A, et al. Molecular profiling pleomorphic lobular carcinomas of the breast: evidence for a common molecular genetic pathway with classic lobular carcinomas. J Pathol. 2008 Jul;215(3):231-44.

45 Rakha EA, Ellis IO. Lobular breast carcinoma and its variants. Semin Diagn Pathol. 2010 Feb;27(1):49-61.
46 Weigelt B, Geyer FC, Natrajan R, Lopez-Garcia MA, Ahmad AS, Savage K, et al. The molecular underpinning of lobular histological growth pattern: a genome-wide transcriptomic analysis of invasive lobular carcinomas and grade- and molecular subtype-matched invasive ductal carcinomas of no special type. J Pathol. 2010 Jan;220(1):45-57.

47 McCart Reed AE, Kutasovic JR, Lakhani SR, Simpson PT. Invasive lobular carcinoma of the breast: morphology, biomarkers and 'omics. Breast Cancer Res. 2015 Jan;17(1):12.

48 Christgen M, Steinemann D, Kühnle E, Länger F, Gluz O, Harbeck N, et al. Lobular breast cancer: Clinical, molecular and morphological characteristics. Pathol Res Pract. 2016 Jul; 212(7):583-97.

49 WHO Classification of Tumours Editorial Board. Breast Tumours. WHO classification of tumours series, 5th ed. Vol. 2. Lyon: International Agency for Research on Cancer; 2019. p. 114-18.

50 Rosen PP, editor. Rosen's breast pathology. 4th ed. Philadelphia (PA): Lippincott Williams \& Wilkins; 2014, Brogi E, pp. 475,4801; Hoda SA, Brogi E, pp. 855-70.

51 Monhollen L, Morrison C, Ademuyiwa FO, Chandrasekhar R, Khoury T. Pleomorphic lobular carcinoma: a distinctive clinical and molecular breast cancer type. Histopathology. 2012 Sep;61(3):365-77.

52 Louwman MW, Vriezen M, van Beek MW, Nolthenius-Puylaert MC, van der Sangen MJ, Roumen RM, et al. Uncommon breast tumors in perspective: incidence, treatment and survival in the Netherlands. Int J Cancer. 2007 Jul;121(1):127-35.

53 Fattaneh AT, Peter D. WHO classification pathology and genetics of tumours of the breast and female genital organs. Lyon: IARC Press; 2003.

54 Rosen PP, editor. Rosen's breast pathology. 4th ed. Philadelphia (PA): Lippincott Williams \& Wilkins; 2014. p. 469-73.

55 Rakha EA, Lee AH, Evans AJ, Menon S, Assad NY, Hodi Z, et al. Tubular carcinoma of the breast: further evidence to support its excellent prognosis. J Clin Oncol. 2010 Jan;28(1):99-104.

56 Rosai J. Rosai and Ackerman's surgical pathology. 10th ed. Elsevier; 2011. p.1698-9.

57 WHO Classification of Tumours Editorial Board. Breast tumours. WHO classification of tumours series. 5th ed. Vol. 2. Lyon: International Agency for Research on Cancer; 2019. p. 119-20.

58 Brandt SM, Young GQ, Hoda SA. The "Rosen Triad": tubular carcinoma, lobular carcinoma in situ, and columnar cell lesions. Adv Anat Pathol. 2008 May;15(3):140-6.

59 Rosen PP, editor. Rosen's breast pathology. 4th ed. Philadelphia (PA): Lippincott Williams \& Wilkins; 2014. p. 452.

60 Min Y, Bae SY, Lee HC, Lee JH, Kim M, Kim J, et al. Tubular carcinoma of the breast: clinicopathologic features and survival outcome compared with ductal carcinoma in situ. J Breast Cancer. 2013 Dec;16(4):404-9.

61 WHO Classification of Tumours Editorial Board. Breast tumours. WHO classification of tumours series. 5th ed. Vol. 2. Lyon: International Agency for Research on Cancer; 2019. p. 120 .
62 Alvarenga CA, Paravidino PI, Alvarenga M, Gomes M, Dufloth R, Zeferino LC, et al. Reappraisal of immunohistochemical profiling of special histological types of breast carcinomas: a study of 121 cases of eight different subtypes. J Clin Pathol. 2012 Dec;65(12): 1066-71.

63 Rosen PP, editor. Rosen's breast pathology. 4th ed. Philadelphia (PA): Lippincott Williams \& Wilkins; 2014. p. 480-2.

64 Wheeler DT, Tai LH, Bratthauer GL, Waldner DL, Tavassoli FA. Tubulolobular carcinoma of the breast: an analysis of 27 cases of a tumor with a hybrid morphology and immunoprofile. Am J Surg Pathol. 2004 Dec; 28(12):1587-93.

65 Esposito NN, Chivukula M, Dabbs DJ. The ductal phenotypic expression of the E-cadherin/catenin complex in tubulolobular carcinoma of the breast: an immunohistochemical and clinicopathologic study. Mod Pathol. 2007 Jan;20(1):130-8.

66 Page DL, Dixon JM, Anderson TJ, Lee D, Stewart HJ. Invasive cribriform carcinoma of the breast. Histopathology. 1983 Jul;7(4): 525-36.

67 Venable JG, Schwartz AM, Silverberg SG. Infiltrating cribriform carcinoma of the breast: a distinctive clinicopathologic entity. Hum Pathol. 1990 Mar;21(3):333-8.

68 Rosen PP, editor. Rosen's breast pathology. 4th ed. Philadelphia (PA): Lippincott Williams \& Wilkins; 2014. p. 749-50.

69 Rakha EA, Reis-Filho JS, Baehner F, Dabbs DJ, Decker T, Eusebi V, et al. Breast cancer prognostic classification in the molecular era: the role of histological grade. Breast Cancer Res. 2010;12(4):207-07.

70 Liu XY, Jiang YZ, Liu YR, Zuo WJ, Shao ZM. Clinicopathological Characteristics and Survival Outcomes of Invasive Cribriform Carcinoma of Breast: A SEER Population-Based Study. Medicine (Baltimore). 2015 Aug;94(31): e1309-09.

71 Zhang W, Zhang T, Lin Z, Zhang X, Liu F, Wang $Y$, et al. Invasive cribriform carcinoma in a Chinese population: comparison with low-grade invasive ductal carcinoma-not otherwise specified. Int J Clin Exp Pathol. 2013; 6(3):445-57.

72 Cong Y, Qiao G, Zou H, Lin J, Wang X, Li X, et al. Invasive cribriform carcinoma of the breast: A report of nine cases and a review of the literature. Oncol Lett. 2015 Apr;9(4): 1753-8.

73 Rasmussen BB, Rose C, Christensen IB. Prognostic factors in primary mucinous breast carcinoma. Am J Clin Pathol. 1987 Feb;87(2): 155-60.

74 Scopsi L, Andreola S, Pilotti S, Bufalino R, Baldini MT, Testori A, et al. Mucinous carcinoma of the breast. A clinicopathologic, histochemical, and immunocytochemical study with special reference to neuroendocrine differentiation. Am J Surg Pathol. 1994 Jul;18(7): 702-11.

75 WHO Classification of Tumours Editorial Board. Breast tumours. WHO classification of tumours series. 5th ed. Vol. 2. Lyon: International Agency for Research on Cancer; 2019. p. 123-5. 
76 Tan PH, Tse GM, Bay BH. Mucinous breast lesions: diagnostic challenges. J Clin Pathol. 2008 Jan;61(1):11-9.

77 Rosen PP, editor. Rosen's breast pathology. 4th ed. Philadelphia (PA): Lippincott Williams \& Wilkins; 2014. p. 611-9.

78 Rosen PP, editor. Rosen's breast pathology. 4th ed. Philadelphia (PA): Lippincott Williams \& Wilkins; 2014. p. 615

79 Liu F, Yang M, Li Z, Guo X, Lin Y, Lang R, et al. Invasive micropapillary mucinous carcinoma of the breast is associated with poor prognosis. Breast Cancer Res Treat. 2015 Jun; 151(2):443-51.

80 Rosen PP, editor. Rosen's breast pathology. 4th ed. Philadelphia (PA): Lippincott Williams \& Wilkins; 2014. p. 619-20.

81 Di Saverio S, Gutierrez J, Avisar E. A retrospective review with long term follow up of 11,400 cases of pure mucinous breast carcinoma. Breast Cancer Res Treat. 2008 Oct; 111(3):541-7

82 Cao AY, He M, Liu ZB, Di GH, Wu J, Lu JS, et al. Outcome of pure mucinous breast carcinoma compared to infiltrating ductal carcinoma: a population-based study from China. Ann Surg Oncol. 2012 Sep;19(9):3019-27.

83 Fisher ER, Palekar AS, Redmond C, Barton B, Fisher B. Pathologic findings from the National Surgical Adjuvant Breast Project (protocol no. 4). VI. Invasive papillary cancer. Am J Clin Pathol. 1980 Mar;73(3):313-22.

84 Nassar H. Carcinomas with micropapillary morphology: clinical significance and current concepts. Adv Anat Pathol. 2004 Nov;11(6): 297-303.

85 Gokce H, Durak MG, Akin MM, Canda T, Balci $\mathrm{P}$, Ellidokuz $\mathrm{H}$, et al. Invasive micropapillary carcinoma of the breast: a clinicopathologic study of 103 cases of an unusual and highly aggressive variant of breast carcinoma. Breast J. 2013 Jul-Aug;19(4):374-81.

86 Vingiani A, Maisonneuve P, Dell'orto P, Farante G, Rotmensz N, Lissidini G, et al. The clinical relevance of micropapillary carcinoma of the breast: a case-control study. Histopathology. 2013 Aug;63(2):217-24.

87 Tang SL, Yang JQ, Du ZG, Tan QW, Zhou YT, Zhang D, et al. Clinicopathologic study of invasive micropapillary carcinoma of the breast. Oncotarget. 2017 Jun;8(26):42455-65.

88 Hao S, Zhao YY, Peng JJ, Ren F, Yang WT, Yu $\mathrm{KD}$, et al. Invasive micropapillary carcinoma of the breast had no difference in prognosis compared with invasive ductal carcinoma: a propensity-matched analysis. Sci Rep. 2019 Jan;9(1):286.

89 WHO Classification of Tumours Editorial Board. Breast tumours. WHO classification of tumours series, 5th ed. Vol. 2. Lyon: International Agency for Research on Cancer; 2019. p. 128-30.

90 Rosen PP, editor. Rosen's breast pathology. 4th ed. Philadelphia (PA): Lippincott Williams \& Wilkins; 2014. p. 763-8.
91 Mills AM, E Gottlieb C, M Wendroth S, M Brenin C, Atkins KA. Pure Apocrine Carcinomas Represent a Clinicopathologically Distinct Androgen Receptor-Positive Subset of Triple-Negative Breast Cancers. Am J Surg Pathol. 2016 Aug;40(8):1109-16.

92 Sapino A, Kulka J, editors, Breast pathology. Encyclopedia of pathology. Berlin: Springer; 2020. p. 29

93 WHO Classification of Tumours Editorial Board. Breast Tumours. WHO classification of tumours series, 5 th ed. Vol. 2. Lyon: International Agency for Research on Cancer; 2012. p. 53-4.

94 Doane AS, Danso M, Lal P, Donaton M, Zhang L, Hudis C, et al. An estrogen receptor-negative breast cancer subset characterized by a hormonally regulated transcriptional program and response to androgen. Oncogene. 2006 Jun;25(28):3994-4008.

95 Vranic S, Schmitt F, Sapino A, Costa JL, Reddy S, Castro M, et al. Apocrine carcinoma of the breast: a comprehensive review. Histol Histopathol. 2013 Nov;28(11):1393-409.

96 Vranic S, Marchiò C, Castellano I, Botta C, Scalzo MS, Bender RP, et al. Immunohistochemical and molecular profiling of histologically defined apocrine carcinomas of the breast. Hum Pathol. 2015 Sep;46(9): 1350-9.

97 Vranic S, Feldman R, Gatalica Z. Apocrine carcinoma of the breast: A brief update on the molecular features and targetable biomarkers. Bosn J Basic Med Sci. 2017 Feb; 17(1):9-11.

98 WHO Classification of Tumours Editorial Board. Breast tumours. WHO classification of tumours series, 5th ed. Vol. 2. Lyon: International Agency for Research on Cancer; 2019. p. 131-3.

99 Rosen PP, editor. Rosen's breast pathology. 4th ed. Philadelphia (PA): Lippincott Williams \& Wilkins; 2014, Brogi E, p. 645-8.

100 Sapino A, Kulka J, editors. Breast pathology. Encyclopedia of pathology. Berlin: Springer; 2020. p. 29-32.

101 WHO Classification of Tumours Editorial Board. Breast tumours. WHO classification of tumours series, 5th ed. Vol. 2. Lyon: International Agency for Research on Cancer; 2019. p. 156-8

102 López-Bonet E, Alonso-Ruano M, Barraza G, Vazquez-Martin A, Bernadó L, Menendez JA. Solid neuroendocrine breast carcinomas: incidence, clinico-pathological features and immunohistochemical profiling. Oncol Rep. 2008 Dec;20(6):1369-74.

103 Rosen LE, Gattuso P. Neuroendocrine Tumors of the Breast. Arch Pathol Lab Med. 2017 Nov;141(11):1577-81.

104 Lavigne M, Menet E, Tille JC, Lae M, Fuhrmann L, Bonneau C, et al. Comprehensive clinical and molecular analyses of neuroendocrine carcinomas of the breast. Mod Pathol. 2018 Jan;31(1):68-82.
105 Rindi G, Klimstra DS, Abedi-Ardekani B, Asa SL, Bosman FT, Brambilla E, et al. A common classification framework for neuroendocrine neoplasms: an International Agency for Research on Cancer (IARC) and World Health Organization (WHO) expert consensus proposal. Mod Pathol. 2018 Dec; 31(12):1770-86

106 WHO Classification of Tumours Editorial Board. Breast tumours. WHO classification of tumours series, 5th ed. Vol. 2. Lyon: International Agency for Research on Cancer; 2019. p. 156-60.

107 WHO Classification of Tumours Editorial Board. Breast tumours. WHO classification of tumours series, 5th ed. Vol. 2. Lyon: International Agency for Research on Cancer; 2019. p. 159-61.

108 Sapino A, Papotti M, Pietribiasi F, Bussolati G. Diagnostic cytological features of neuroendocrine differentiated carcinoma of the breast. Virchows Arch. 1998 Sep;433(3):217-22.

109 Sapino A, Righi L, Cassoni P, Papotti M, Pietribiasi F, Bussolati G. Expression of the neuroendocrine phenotype in carcinomas of the breast. Semin Diagn Pathol. 2000 May; 17(2):127-37.

110 Righi L, Sapino A, Marchiò C, Papotti M, Bussolati G. Neuroendocrine differentiation in breast cancer: established facts and unresolved problems. Semin Diagn Pathol. 2010 Feb;27(1):69-76.

111 Wang J, Wei B, Albarracin CT, Hu J, Abraham SC, Wu Y. Invasive neuroendocrine carcinoma of the breast: a population-based study from the surveillance, epidemiology and end results (SEER) database. BMC Cancer. 2014 Mar;14(1):147.

112 WHO Classification of Tumours Editorial Board. Breast tumours. WHO classification of tumours series, 5th ed. Vol. 2. Lyon: International Agency for Research on Cancer; 2019. p. 105

113 Weigelt B, Geyer FC, Horlings HM, Kreike B, Halfwerk H, Reis-Filho JS. Mucinous and neuroendocrine breast carcinomas are transcriptionally distinct from invasive ductal carcinomas of no special type. Mod Pathol. 2009 Nov;22(11):1401-14.

114 Marchiò C, Geyer FC, Ng CK, Piscuoglio S, De Filippo MR, Cupo M, et al. The genetic landscape of breast carcinomas with neuroendocrine differentiation. J Pathol. 2017 Feb;241(3):405-19.

115 Liu N, Johnson KJ, Ma CX. Male Breast Cancer: An Updated Surveillance, Epidemiology, and End Results Data Analysis. Clin Breast Cancer. 2018 Oct;18(5):e997-1002.

116 Rosen PP, editor. Rosen's breast pathology. 4th ed. Philadelphia (PA): Lippincott Williams \& Wilkins; 2014. p. 976.

117 Humphries MP, Sundara Rajan S, Honarpisheh H, Cserni G, Dent J, Fulford L, et al. Characterisation of male breast cancer: a descriptive biomarker study from a large patient series. Sci Rep. 2017 Mar;7(1):45293-93. 